\title{
ЮРИДИЧНА ВІДПОВІДАЛЬНІСТЬ ЗА ПОРУШЕННЯ ЗАКОНОДАВСТВА У СФЕРІ ЗАСТОСУВАННЯ ДОПОМІЖНИХ РЕПРОДУКТИВНИХ ТЕХНОЛОГІЙ У МІЖНАРОДНОМУ ПРИВАТНОМУ ПРАВІ
}

\author{
ДАВИДЮК Христина Валеріївна - аспірант кафедри міжнародного \\ приватного права, Інституту міжнародних відносин Київського національного \\ університету ім. Т. Шевченко \\ ORCID ID 0000-0003-2726-3604 \\ УДК 347.6 \\ DOI 10.32782/NP.2021.3.25
}

\begin{abstract}
Міжнародне право містить безліч положень, що стосуються допоміжних репродуктивних технологій у иілому та сурогатного материнства зокрема в різних аспектах. Це в основному стандарти прав дітей, заборона продажу дітей та торгівлі людьми, а також стандарти міжнародного усиновлення. у статті розглядається питання правового забезпечення відповідальності за порушення законодавства у сфері застосування допоміжних репродуктивних технологій на територіӥ країн - членів $E C$, а також проведено порівняльний аналіз реалізачй міжнародних норм, що регулюють відносини, пов'язані з юридичною відповідальністю за порушення законодавства у сбері застосування допоміжних репродуктивних технологій. Автор виділив транскордонні проблеми сурогатного материнства на основі судової практики Европейського суду з прав людини. Однак в умовах належного правового регулювання зазначених суспільних відносин виникає інша сочіальна проблема - проблема зловживання допоміжними медичними репродуктивними технологіями. На підставі проведених досліджень пропонується авторсъке бачення законодавчого регулювання иієі проблеми.

Автор також приходить до висновку що подолання колізійних проблем застосування юридичної відповідальності за порушення законодавства у сбері застосування допоміжних репродуктивних технологій можливо шляхом уніббкаціӥ законодавств у рамках регіональних міжнародних організацій. Причому окрему
\end{abstract}

увагу має бути приділено приниципу автономї волі сторін («lex voluntatis»). Держави - члени EC повинні розробити загальні норми, які дозволили б різним нормам національного законодавства діяти в транскордонних ситуаціях при повазі до основних прав громадян $i$ забезпечення правової визначеності. Ця робота на глобальному рівні необхідна і актуальна, оскільки міжнародні угоди про застосування допоміжних репродуктивних технологій передбачають відносини між громадянами EC i третіх країн, а також колізї законів $і$ юрисдикиій з третіми краӥнами.

Ключові слова: репродуктивні технологї, відповідальність, сурогатне материнство, визнання батьківства, Европейсъкий суд з прав людини, громадянство, батьки, міжнародна угода.

Постановка проблеми у загальному вигляді та їі зв'язок із важливими науковими чи практичними завданнями

Сформоване в науці поняття «допоміжні репродуктивні технології» об’ єднує в собі різні медичні технології, методи лікування безпліддя і відповідні цьому процесу процедури. Екстракорпоральне запліднення, донорство сперми і яйцеклітин, допомога сурогатних матерів - усе це відноситься до категорії «допоміжні репродуктивні технології». Саме цим і обумовлюється необхідність диференціації правового, у тому числі і колізійного, регулювання, застосування різних методів допоміжних репродуктивних технологій. У світовій практиці 
ставлення до допоміжних репродуктивних технологій: правові системи одних держав його законодавчо дозволяють, інших - забороняють, третє - не містять правової регламентації. Відсутність єдиного підходу до цієї проблематики породжує ситуацію, коли громадяни однієї держави перетинають кордон іноземної держави 3 метою здійснення своїх репродуктивних прав за допомогою реалізації зазначеного виду допоміжних репродуктивних технологій, внаслідок чого виникають правовідносини, ускладнені іноземним елементом. У зв'язку 3 цим залишаються відкритими багато питань, що виникають у сфері правового регулювання відносин сурогатного материнства в міжнародному приватному праві, що зумовлює актуальність обраної теми наукового дослідження. Яка специфіка відносин у сфері юридичної відповідальності за порушення законодавства щодо застосування допоміжних репродуктивних технологій, ускладнених іноземним елементом? Правом якої країни повинні регулюватися зазначені правовідносини? Вирішення поставлених запитань дозволить захистити найменш захищеного суб'єкта правовідносини - дитину, народжену сурогатною матір'ю. Фактичні батьки-іноземці, у яких вона знаходиться на вихованні, можуть не визнаватися такими юридично в державі їх громадянства, де цей вид допоміжних репродуктивних технологій заборонений.

Оскільки в багатьох країнах введені різноманітні законодавчі заборони у сфері використання допоміжних репродуктивних технологій, з одного боку, і наявність жінок, згодних за середню оплату надати репродуктивну послугу - 3 іншого, подібного роду відносини будуть усе більш розвиватися і міцніти. Відсутність належного правового регулювання на міжнародному рівні тягне за собою ряд колізій щодо використання допоміжних репродуктивних технологій. Зокрема, питання викликає вибір застосовного права при встановленні договірних відносин, при встановленні батьківства або материнства, при донорстві статевих клітин, а також форми відповідальності за порушення умов застосування допоміжних репродуктивних технологій.
Аналіз останніх досліджень і публікацій, у яких започатковано розв'язання цієї проблеми і на які спирається автор, виділення не вирішених раніше частин загальної проблеми, котрим присвячується означена стаття

3 різних аспектів аналізу юридичної відповідальності за порушення законодавства у сфері застосування допоміжних репродуктивних технологій у міжнародному приватному праві досліджували у вітчизняній та зарубіжній юридичній літературі такі автори, як: Дробишевська, О. Баллаєва, А. Красавчикова, Г. Романовський, 3. Ромовська, О. Аукашова, К. Світнев, Р. Стефанчук, I. Сенюта, С. Стеценко, О. Хазова, Greil A., Slauson-Blevins K., Lowry M., Xapaджа, П. Холлендер Chazan L, Kushnir Т. та інші. У зазначених наукових дослідженнях юридична відповідальність за порушення законодавства у сфері застосування допоміжних репродуктивних технологій розглядаються загалом у контексті захисту права на життя чи на здоров'я або ж в аспекті реалізації репродуктивних прав.

\section{Формулювання цілей статті (постановка завдання)}

Мета наукового дослідження полягає у проведенні комплексного аналізу юридичної відповідальності за порушення законодавства у сфері застосування допоміжних репродуктивних технологій у міжнародному приватному праві.

Виклад основного матеріалу
дослідження з повним обгрунтуванням
отриманих наукових результатів
Міжнародне право містить безліч поло-
жень, що стосуються допоміжних репродук-
тивних технологій у цілому та сурогатного
материнства зокрема в різних аспектах. Це
в основному стандарти прав дітей, заборо-
на продажу дітей та торгівлі людьми, а та-
кож стандарти міжнародного усиновлення.
у деяких випадках сурогатне материнство-
це відвертий продаж дитини і шахрайство
відповідно до міжнародного законодавства
про усиновлення. Законодавчий компро-
міс у сфері репродукції часто представле-


ний як альтернатива між абсолютною забороною і дозвільним регулюванням сурогатного материнства. Відповідальність за порушення законодавства у сфері застосування допоміжних репродуктивних технологій регулюється різними способами в різних державах-членах EC. Наприклад, у таких країнах, як Франція, Німеччина та Данія, сурогатне материнство не вітається, так як «суперечить законодавству про усиновлення і порушує положення про невідчужуваності людського тіла» [1; с. 55], але i не заборонено законом. У Німеччині та Франції до відповідальності притягуються лікарі і посередники, а не генетичні батьки та сурогатна матір. У Німеччині вважається злочином будь-яка спроба реалізації штучного запліднення або імплантації людського ембріона жінці (сурогатної матері), готової відмовитися від своєї дитини після його народження. У Данії дозволено тільки некомерційне сурогатне материнство, однак зі значними обмеженнями. Для жителів Франції сурогатне материнство не є законним як таке, що суперечить законодавству про усиновлення. Інші країни - наприклад, Греція та Великобританія - використовують цю практику, якщо вона не є комерційною. [1; с. 55]

Крім етичних і юридичних дискусій, практика міжнародних угод сурогатного материнства зачіпає ряд питань міжнародного приватного права і основних прав, які безпосередньо впливають на життя громадян. До числа цих питань відносяться визначення громадянство дитини, право на сімейне життя. У той час як сімейне право в цілому та сурогатне материнство, зокрема, є головним чином питаннями національної компетенції, EC має право діяти з тих аспектів, які мають транскордонні наслідки, ця норма вказана в статті 81 (3) Договору про функціонування Европейського Союзу ( TFEU) [2].

Можлива потреба в активізації дій EC обговорювалася раніше в дослідженні, опублікованому Департаментом політики в 2010 році ( «Визнання батьківської відповідальності: біологічне батьківство») [3]. Правові питання пов'язані головним чином 3 відмовою у визнанні іноземних свідоцтв про народження, дітей, народжених сурогатною матір'ю. Відсутність міжнародного регулювання міжнародних угод про сурогатне материнство залишило питання юридичної відповідальності на розсуд суддів. Дійсно, в Европейському суді з прав людини (ССП $\mathcal{~ ) ~ б у л о ~ о с к а р ж е н о ~ к і л ь к а ~ в і д м о в ~ у ~}$ визнанні угод про застосування допоміжних репродуктивних технологій i різних наслідків, викликаних порушенням права дитини на повагу до приватного і сімейного життя (стаття 8 Европейської конвенції про права людини). [4]

Відмова держав, які не визнають сурогатне материнство, визнавати іноземні свідоцтва про народження, що випливають 3 договору про сурогатне материнство, означає, що дітям, які народилися в таких обставинах, відмовляють у праві клопотати про надання громадянства держави їх проживання. Така відмова зареєструвати народження дитини в національному реєстрі актів громадянства має ряд наслідків, які завдають шкоди, насамперед, самій дитині. Так прикладом є справа щодо Меннессона i Лабассі, їм було відмовлено в наданні громадянства [5, 6].

У результаті було дійсно підкреслено, що ця відмова призвела до обмеження прав дитини за французьким законом про спадкування, [7; с.94] а також практичні труднощі, пов'язані з соціальним забезпеченням i шкільною освітою. ЄСПЛ, слідуючи своїй попередній практиці, продиктованої основоположним принципом найкращого забезпечення інтересів дитини, підтвердив, що дитина, народжена 3 використанням репродуктивних технологій та сурогатного материнства, не повинна перебувати в несприятливому становищі через спосіб свого народження. Судді прийшли до висновку, що такі наслідки, що випливають 3 відмови в наданні громадянства, є порушенням права дитини на приватне життя. Це рішення було недавно підтверджено у справі Фулон проти Франції, у якій заявник скаржився на те, що його дитина не має права відкривати банківський рахунок у Франції, оскільки їй було відмовлено в громадянстві [8].

Також після народження дитини виникає правовий вакуум, який залишає від- 
критим питання про те, хто є законними батьками дитини: сурогатна мати або генетичні батьки. Франція і Італія відмовилися встановити законну спорідненість між дитиною і батьками відповідно до свого національного законодавства. У зв'язку з цим ЕСПЛ постановив, що право дитини на повагу до приватного життя було порушено, оскільки відсутність спорідненості негативно позначиться на формуванні особистості дитини та на право дитини на збереження індивідуальності, що є несумісним 3 інтересами дитини. Одним 3 основних питань, порушених у справі Парадізо і Кампанеллі проти Італії, було вилучення дитини 3 сімейного оточення після відмови італійської держави визнати свідоцтво про народження дитини [9]. Згідно з прецедентною практикою $\mathrm{ECП \lambda ,} \mathrm{існування} \mathrm{сімейного}$ життя залежить головним чином від наявності фактичних зв'язків. Таким чином, навіть не зважаючи на те, що італійська влада не вважає біологічних батьків законними батьками дитини, вони розглядаються як іiі фактичні соціальні батьки. Таким чином, EСПЛ дійшов висновку про те, що мало місце порушення права дитини на сімейне життя, оскільки він вважав рішення про виключення дитини 3 сімейного оточення крайнім заходом, яку державні органи не повинні використовувати. Крім того, було підкреслено, що навіть право на приватне життя в певній мірі тягне за собою право індивіда встановлювати відносини 3 «іншими людьми» [10; с. 363].

Згідно 3 прецедентною практикою EСП $\lambda$, відмова у визнанні іноземних свідоцтв про народження сурогатних дітей $\epsilon$ порушенням основного права дитини на приватне та сімейне життя в силу наслідків, які воно тягне за собою. Деякі експерти стверджують, що єдине, що необхідно зробити-це адаптувати чинну систему міжнародного усиновлення до випадків, передбачених міжнародними угодами про застосування допоміжних репродуктивних технологій, у той час як для інших способів вирішення проблеми існує необхідність у розробці окремого міжнародного документа, присвяченого сурогатному материнству. Тим часом певна робота вже проводиться на міжнародних форумах, таких, як Гаазька конференція з міжнародного приватного права (міжурядова організація) або Міжнародна Соціальна служба (НУО).

A. Гpeiл (Greil AL, Slauson-Blevins KS, Lowry M, et al. (2019)) зазначає, що міжнародні угоди про використання репродуктивних технологій висвітлюють класичні проблеми міжнародного приватного права, на які необхідно відповісти глобальним регулюванням: визначення компетентного суду, законодавство, яке застосовується щодо встановлення юридичного походження, єдиний порядок притягнення до відповідальності за порушення законодавства у сфері застосування допоміжних репродуктивних технологій у міжнародному приватному праві. Вони підкреслюють, що визначення законного походження має грунтуватися тільки на найкращих інтересах дитини [11; с. 16].

Крім того, колізії можуть виникнути при встановленні походження дитини, народженої в результаті застосування допоміжних репродуктивних технологій. На жаль, колізійно-правове регулювання застосування допоміжних репродуктивних технологій відстає від темпів розвитку медичних способів і методик лікування безпліддя. Вітчизняне і зарубіжне законодавство про міжнародне приватне право не містить спеціальних колізійних прив'язок щодо регулювання договорів у сфері допоміжних репродуктивних технологій і встановлення походження дітей у результаті їх застосування. Найбільш компромісним видом допоміжних репродуктивних технологій є екстракорпоральне запліднення. Воно є методом лікування безпліддя, при використанні якого яйцеклітина жінки вилучається з їі організму і запліднюється в штучних умовах. У більшості країн світу допускається можливість запліднення яйцеклітини дружини спермою чоловіка. Наприклад, законодавство Ісламської Республіки Іран, незважаючи на негативне ставлення до допоміжних репродуктивних технологій, усе ж допускає можливість застосування штучного запліднення як методу лікування безпліддя при використанні генетичного матеріалу подружжя. Наявність генетичного 


\section{Міжнародне право}

зв’язку між батьками і дитиною, народженою в результаті застосування екстракорпорального запліднення, дозволяе в законодавчому порядку визнати в подальшому його походження від них. [12]

Безумовно, планування дитини, у тому числі і шляхом застосування методу екстракорпорального запліднення, 6 справою кожної окремої сім'ї. Однак інтереси дитини, народженої в результаті екстракорпорального запліднення (особливо при застосуванні донорського матеріалу), повинні мати пріоритет при розробці колізійних норм. Вищевикладене дозволяє зробити висновок про необхідність розвитку колізійного регулювання притягнення до відповідальності за порушення порядку застосування методу екстракорпорального запліднення на рівні міжнародних договорів і внутрішньодержавного законодавства.

У зв'язку з тим, що відносини між батьками і дітьми 3 так званим «іноземним елементом» відрізняються особливою складністю, колізійні проблеми юридичної відповідальності сторін зазначених правовідносин, вимагають особливого регулювання в колізійному сімейному праві. У різних країнах використовуються відмінні один від одного колізійні прив'язки: до місця народження дитини; до постійного місця проживання батьків дитини; до країни громадянства батьків дитини та ін. Подібні відмінності мають місце у відносинах залежно від того, чи є дитина народженою у шлюбі чи ні. Залежить також і від того, яким чином вона зачата - природним шляхом або в результаті застосування допоміжних репродуктивних технологій.

Найбільш яскраво виражені відмінності у порядку притягнення до відповідальності за порушення законодавства про допоміжні репродуктивні технології, коли мова йде про зовсім різні за своєю суттю системи права, наприклад про англосаксонську або мусульманську системи. Наприклад, закон Австрії «On international private law» від 1978 р. містить у собі різні колізійні принципи щодо шлюбного або позашлюбного походження дитини. 3 появою дитини на світ, як справедливо відзначається Т. Кушнip (Chazan L, Kushnir T. (2019)), у іï бать- ків (незалежно від спільного або окремого проживання), а також від наявності або відсутності зареєстрованого шлюбу виникає моральний обов'язок перед нею [13]. Проблема відносин батьків і дітей може ускладнюватися зв'язком 3 різними державами. Подібне може статися в тих випадках, якщо батьки мають громадянство різних держав, якщо вони мають місце проживання в різних державах або якщо при народженні дитини проживають на території, що відноситься до іноземної держави.

В Азербайджані, Бразилії, Угорщини, Вірменії, Великобританії, Ізраїлі, Індії, Казахстані, Канаді, Грузії, Узбекистані, Нідерландах, Гонконгу, США (в деяких штатах), ПАР сурогатне материнство дозволено.У свою чергу, у таких країнах, як Австрія, Швейцарія, Німеччина, Франція, Норвегія, Швеція, сурогатне материнство заборонено законом. [13] У світі є навіть країни, де законом повністю заборонено тільки комерційне сурогатне материнство і не допускаються судові позови за такими угодами. До таких країн належать Нідерланди, Швейцарія, Норвегія, Греція, Іспанія.

Так, відповідно до ст. 10 закону Іспанії «Sobre tecnologías de reproducción adicional de personas» («Про технології допоміжної репродукції людини») від 26 травня 2006 № 14, вважається недійсним договір, який передбачає відмову від материнства на користь третіх осіб. Таким чином, презумпція материнства жінки, що народила в цій країні, непохитна. Але, згідно із загальними нормами права, передбачається можливість генетичного батька щодо подання позову щодо встановлення батьківства. Між тим донорство статевих клітин в Іспанії не тільки не заборонено, але і належним чином врегульовано законодавцем. Так, дозволено не тільки безкоштовне, але і оплачуване донорство, а також і посмертне використання дружиною статевих клітин їі чоловіка протягом року після його смерті. Так, у ст. 9 цього Закону говориться, що протягом життя чоловік шляхом письмової згоди, нотаріального акту або заповідального розпорядження має право дати згоду на те, щоб його репродуктивний матеріал був використаний 3 метою запліднення 
його дружини в термін до 12 місяців 3 дня його смерті. У цьому випадку чоловік буде визнаний як законний батько дитини, яка народилася після смерті батька. Крім того, закон також передбачає можливість для померлої жінки стати матір'ю, якщо иіі чоловік або співмешканець звернеться в клініку для використання ембріонів, що раніше зазнали кріоконсервації.

Складнощі транскордонного регулювання в цьому випадку можуть полягати також і в тому, що в одних країнах право на використання кріоконсервінованних статевих клітин має тільки чоловік (дружина) померлої особи, а в інших - інші особи, крім зазначених. Уявімо ситуацію, коли особи, які перебувають у цивільному шлюбі і є громадянами різних держав, кріоконсервовують ембріони в медичній установі. Після смерті жінки ії співмешканець вирішив використовувати ембріони, проте батьки жінки, які проживають в іншій державі, не згодні з цим рішенням, так як, на їхню думку, співмешканець їхньої дочки навіть не припадав їй чоловіком. Пошук правомірного рішення в подібній ситуації може створити деякі труднощі.

Японське законодавство також не відповідає однозначно на питання про сурогатне материнство. Так, генетичні батьки не визнаються батьками на території держави свого громадянства, - такими вони можуть бути визнані тільки в країні здійснення сурогатного материнства. У результаті в Японії (так само, як і в Іспанії) можуть виникнути відносини, у результаті яких громадяни змушені проходити процедуру усиновлення своїх власних дітей на території іноземної держави. У разі ж недотримання норм чинного законодавства своєї країни в галузі використання допоміжних репродуктивних технологій щодо осіб-учасників угоди про сурогатне материнство до порушників застосовуються заходи відповідальності, відбувається невизнання родинних зв'язків між дитиною і генетичними батьками. Крім того, існують деякі складності у сфері отримання дитиною громадянства, з правом виїзду і в’їзду на територію держави, а також інші проблеми.
Сьогодні існує об'єктивна необхідність у регіональному співробітництві у сфері врегулювання відносин при використанні допоміжних репродуктивних технологій. Використання закону країни походження генетичних батьків не завжди може сприяти адекватному регулюванню відносин, так як часто може мати місце заборона застосування методу сурогатного материнства. «Замовники», як правило, здійснюють виїзд за межі країни, громадянами якої вони $\epsilon, 3$ метою зниження витрат, пов'язаних 3 виконанням договору про сурогатне материнство, а також з метою обходу несприятливого правового впливу норм, що діють у країні свого власного походження. Тут мова йде про заборону застосування деяких видів допоміжних репродуктивних технологій i, як наслідок, про настання відповідальності за використання таких способів лікування безпліддя. Звичайно, при укладанні угоди про сурогатне материнство так чи інакше необхідно брати до уваги ставлення до нього з боку законодавства країни походження генетичних батьків, оскільки в разі кардинального заборони використання методу сурогатного материнства укладення договору може стати проблемним, так як при заборону особистим законом усі подальші відносини між дитиною, народженою в результаті використання допоміжних методів репродукції.

Колізійне регулювання взаємовідносин щодо відповідальності за порушення законодавства у сфері застосування допоміжних репродуктивних технологій має свою специфіку в більшості країн зарубіжжя. Так, в одних країнах як визначальної колізійної прив'язки для регулювання особистих немайнових відносин дитини (у тому числі і iii захисту) застосовується право місця народження дитини (ст. 3093 Цивільного кодексу Квебеку; § 24 закону Австрії «Про міжнародне приватне право» від 1978 р , ст. 16 закону Об'єднаних Арабських Еміратів про громадянські угоди 1985 р.); в інших - закон місця виникнення спору (ст. 27 Цивільного кодексу Емену 1992 г.); по-третє, застосовується законодавство тієї держави, яке регулює походження дитини [10, с. 364]. 


\section{Міжнародне право}

Наявність «іноземного елемента» обумовлює те, що вибір правопорядку з регулювання відносин, що виникають у результаті застосування допоміжних репродуктивних технологій, повинен здійснюватися на основі принципу «lex voluntatis» (автономія волі сторін), який займає не останнє місце в колізійному регулюванні договорів. Колізійні прив'язки у сфері застосування допоміжних репродуктивних технологій повинні відображати специфіку укладання відповідної угоди. Особливе місце серед таких договорів займає договір про сурогатне материнство. У юридичній літературі 3 приводу можливості вибору застосовуваного права висловлюються різні думки. Так, деякими вченими-правознавцями вказується на необхідність надання сурогатній матері і генетичним батькам можливості вибору застосовуваного права 3 кількох конкретних варіантів, у які включені: право країни, у якій дитина народжена, право країни постійного проживання сурогатної матері, право країни постійного проживання генетичних батьків. Міжнародні приватно-правові відносини визнають принцип «lex voluntatis» одним 3 основоположних начал, метою якого 6 «виявлення можливих для застосування матеріальноправових норм, визначення автономії волі сторін при підборі застосовного права до їх відносин» [12].

Правове регулювання юридичної відповідальності за порушення законодавства у сфері застосування допоміжних репродуктивних технологій у міжнародному приватному праві лише за допомогою імперативних колізійних прив'язок не відповідає інтересам не тільки сторін, але i самої дитини, народженої в результаті застосування допоміжних репродуктивних технологій. Жорсткі колізійні прив'язки в сучасному суспільстві йдуть на другий план, поступаючись місцем принципу автономії волі, який дає можливість втручання в реальний процес шляхом вибору певного правопорядку регулювання договірних відносин. Сфера сімейного права також надає можливість застосування принципу автономії волі як у разі укладення шлюбного договору, так і при укладанні договору
3 передачі аліментів. Застосування заходів внаслідок невиконання (або неналежного виконання) договору, у свою чергу, буде регулюватися за допомогою законодавства, на основі принципу автономії волі сторін.

\section{Висновки з даного дослідження і перспективи подальших досліджень у даному напрямі}

Отже, подолання колізійних проблем застосування юридичної відповідальності за порушення законодавства у сфері застосування допоміжних репродуктивних технологій можливо шляхом уніфікації законодавств у рамках регіональних міжнародних організацій. Причому окрему увагу має бути приділено принципу автономії волі сторін («lex voluntatis»). Держави - члени EC повинні розробити загальні норми, які дозволили 6 різним нормам національного законодавства діяти в транскордонних ситуаціях при повазі до основних прав громадян і забезпечення правової визначеності. Ця робота на глобальному рівні необхідна і актуальна, оскільки міжнародні угоди про застосування допоміжних репродуктивних технологій передбачають відносини між громадянами EC і третіх країн, а також колізії законів і юрисдикцій з третіми країнами.

\section{入iтература}

1. Dickens B. M., Cook R. J. (2019) Some ethical and legal issues in assisted reproductive technology: Ethical and legal issues in reproductive health // International Journal of Gynecology \& Obstetrics. 1 July 2019. Vol. 66, issue 1. P. 55-61.

2. Treaty on the Functioning of the European Union - Protocols - Annexes - Declarations annexed to the Final Act of the Intergovernmental Conference which adopted the Treaty of Lisbon, signed on 13 December 2007 - Tables of equivalences. Official Journal C $326,26 / 10 / 2012$ P. $0001-0390$

3. Дослідження Департаменту політики 2010 «Визнання батьківської відповідальності: біологічне батьківство» URL: $\quad$ http://www.europarl.europa.eu/RegData/etudes/STUD/2010/432738/IPOL-JURI NT(2010)432738 EN.pdf. (Дата звернення 11.04.2021p.) 
4. Европейська конвенція 3 прав людини URL: $\underline{\text { https://www.echr.coe.int/ }}$ Documents/Convention_RUS.pdf (Дата звернення 11.04.2021р.)

5. Mennesson v. France, ECtHR, Application No. 65192/11, 26 June 2014 URL: https://blogdroiteuropeen.files.wordpress. com/2017/12/case-of-mennesson-v-france-extracts.pdf (Дата звернення 11.04.2021p.)

6. Labasse v. France, ECtHR, Application No. 65941/11, 26 June 2014 URL: http://www.consultant.ru/cons/ cgi/online.cgi ? req $=$ doc \&base $=$ ARB 002 $\& \mathrm{n}=412405 \# 0662367255477246$

7. Inhorn M. C., Patrizio P. (2019) Rethinking reproductive "tourism" as reproductive "exile" // Fertility \& Sterility. 2019.№ 92(3). P. 904-906.

8. Fulon v. France, ECtHR, Application No. 9063/14, 21 July 2016 URL: https://www. hrlc.org.au/human-rights-case-summaries/ echr-finds-failure-to-recognise-fathers-ofchildren-born-as-a-result-of-international-commercial-surrogacy-violates-the-right-to-privacy

9. Paradiso and Campanelli v. Italy, ECtHR, Application No. 25358/12, 27 January 2015 URL: http://www.consultant.ru/ cons/cgi/online.cgi ?req = doc\&base $=$ ARB $\underline{\& \mathrm{n}=506071 \# 0748383784286687}$

10. Whittaker A., Speier A. (2020) "Cycling overseas": care, commodification and stratification in cross-border reproductive travel // Medical Anthropology. 2020. Oct. 29(4).P. 363-383.

11. Greil AL, Slauson-Blevins KS, Lowry M, et al. (2019) Concerns about treatment for infertility in a probability-based sample of US women. Journal of Reproductive and Infant Psychology 38: 16-24.

12. Piersanti V., Consalvo F., Signore F., Del Rio, A., \& Zaami, S. (2021). Surrogacy and "Procreative Tourism". What Does the Future Hold from the Ethical and Legal Perspectives?. Medicina (Kaunas, Lithuania), 57(1), 47. https://doi.org/10.3390/medicina57010047

13. Chazan L, Kushnir T. (2019) Losses and gains of psychosocial resources: Effects on stress among women undergoing infertility treatments and participating in social network systems. Psychiatric Quarterly 90: 717-732.
Davydiuk Khrystyna, postgraduate Private International Law Chair, Institute of international relations Taras Shevchenko National University of Kyiv

LEGAL RESPONSIBILITY FOR VIOLATION OF LEGISLATION IN THE FIELD OF APPLICATION OF ASSISTED REPRODUCTIVE TECHNOLOGIES IN THE INTERNATIONAL PRIVATE LAW

International law contains a number of provisions relating to assisted reproductive technologies in general and surrogacy in particular in various respects. These are mainly the standards of children's rights, the prohibition of the sale of children and human trafficking, as well as the standards of international adoption. The article considers the issue of legal liability for violations of legislation in the field of assisted reproductive technologies in the EU member states, and provides a comparative analysis of the implementation of international provisions governing legal liability for violations of legislation in the field of assisted reproductive technologies. The author identified cross-border problems of surrogacy based on the case law of the European Court of Human Rights. However, there is another social problem under the conditions of proper legal regulation of these social relations - the problem of abuse of assisted medical reproductive technologies. The author's vision of legislative regulation of this problem is offered on the basis of the conducted studies.

The author also concludes that overcoming the conflicting problems of legal liability for violations of legislation in the field of assisted reproductive technologies is possible by unifying legislation within regional international organisations. Moreover, special attention should be paid to the principle of autonomy of the will of the parties (lex voluntatis). EU Member States must develop common rules that would allow different rules of national law to operate in cross-border situations while respecting the fundamental rights of citizens and ensuring legal certainty. This work is necessary and topical at the global level, as international agreements on the use of assisted reproductive technologies provide for relations between EU and third-country nationals, as well as conflicts of laws and jurisdictions with third countries.

Key words: reproductive technologies, liability, surrogacy, recognition of paternity, European Court of Human Rights, citizenship, parents, international agreement. 